\title{
Risk Assessment of Heavy Metals in Wild and Farmed Clarias gariepinus (Burchell, 1822) in Zaria, Kaduna State, Nigeria
}

\section{Onyidoh Henry Eric, Ismail Falalu Muhammad, Muhammad Ahmad Muhammad \& Idris Jaafar Abdullahi}

\author{
Department of Biology, Faculty of Life Sciences, A.B.U, Zaria
}

\section{ARTICLE INFO}

Article No.: 110217163

DOI: 10.15580/GJAS.2018.1.110217163

Submitted: 02/11/2017

Accepted: 07/11/2017

Published: $27 / 01 / 2017$

${ }^{*}$ Corresponding Author

Onyidoh Henry Eric

E-mail: anreaeryck@gmail.com

Keywords: Daily intake of Metals, Health risk index, Heavy metals, Risk assessment
The likely health risks developed as a result of human contamination by heavy metal through fish consumption was assessed in this study. The analysis of wild and farmed fish for heavy metals was determined and an assessment of the risk limits was evaluated through daily intake of metal and health risk index. Heavy metals accumulations varied in concentrations in the various tissues/organs (skin, muscle, gills, liver, intestine, kidneys, brain, and bones) across the groups of farmed and wild fish species (Clarias gariepinus). A post-hoc multi-comparison (Duncan Multiple Range Test) showed that there were significant differences $(P<$ 0.05 ) across analysed samples. The analysis of heavy metals concentrations, in the investigated tissues of Clarias gariepinus, showed levels of heavy metals accumulations in the order: $\mathrm{Fe}>\mathrm{Hg}>\mathrm{Pb}>\mathrm{Cd}>\mathrm{Ni}$ and were all below the recommended safety limits outlined by FAO/WHO. Furthermore, the consumer's health risk with the consumption of fish muscles tissues shows that there are very negligible tendencies for cadmium, lead, and mercury exposure. Also the ingestion of Clarias gariepinus with heavy metal concentrations indicated in this study is within the FAO/WHO safety daily intake limits (also specified in the study) and would not result in accumulation of heavy metals at intolerable concentrations, thus health complications arising from accumulation of heavy metals are rare. 


\section{INTRODUCTION}

In recent years, concentrations of heavy or toxic metals have reached unprecedented levels in many ecosystems. The use of metals in industries and other anthropogenic activities have increased over the years, and have led to very serious environmental pollution through effluents and emanations (Osman and Kloas, 2010; Ashraf et al., 2012; Herger and Edmond, 2012). Heavy metals, under certain accumulated concentrations may become toxic (Güven et al., 1999), and has the potential of causing severe damages to various ecosystems, especially in aquatic systems (Allen et al., 1993; Meybeck et al., 1996; Jafari and Gunale, 2006). Aquatic ecosystems are more sensitive to heavy metals pollutants and the steady increase of these metals in the environment, primarily due to anthropogenic activities, such as accidental spillage of chemical wastes, discharge of industrial or sewerage effluents, agricultural drainage, domestic wastewater and gasoline from fishery boats, has become a source of concern (Allen et al., 1993; Handy, 1994; Ali and Soltan, 1996; Meybeck et al., 1996). Aquatic pollution is thus a cosmopolitan problem which requires urgent attention and prevention (Handy, 1994; Ali and Soltan, 1996; Osman, 2007; Osman and Kloas, 2010), as heavy metals are persistent, due to their low biodegradability and slow chemical disintegration process, compared to organic pollutants; which in addition to detritus formed by natural weathering processes provides rich nutrients for aquatic organisms (Jafari and Gunale, 2006; Ibeto and Okoye, 2010). Microflora, algae and other aquatic microbes are capable of incorporating and accumulating these heavy metals into their cells, which consequently are ingested by small fishes, which thus becomes enriched with these accumulated substances and subsequently the entire food chain showing higher concentrations at each trophic level (Ashraf, 2012). While fish occupies the highest trophic level in the aquatic ecosystem, man who derives nutrients from fishes, dating back to over 40,000 years ago (Hu et al., 2009), eventually and inevitably suffers from the effects of an enrichment process which has taken place in each trophic level, where less is extracted than ingested (Forstner and Wittmann, 1983). Fishes are an important aspect of human life, such that its demand as nutrition has led to its capture and rearing in both the wild and aquaculture mediums. However, irrespective of their economical and nutritional benefits, fishes respond to various environmental changes and can be used as a bioindicator for pollution indication studies. Of the over 32,800 species of fishes, the African Catfish (Clarias gariepinus) is among the most popular in Nigeria's wild waters and aquaculture media (Amos and Bolorunduro, 2000), this is primarily due to their fast growth, hardiness, resistance to diseases, easy to breed both in captivity and wild. However, with these merits comes some drawbacks, as several studies have shown that wild captured fishes with potential of being hardy, bio-accumulate heavy metals to a large extent that has far-reaching health risks (Brown and Walls, 1997; Yilmaz, 2003; Hajeb et al., 2009; Olaifa et al., 2010; Mieiro et al., 2012; Bashir et al., 2013). With the growing awareness of eating healthy, there has been a rising consumption of both wild and farmed fish meat in Nigeria, this is in addition to the very low level of consumer safety control in place and inadequate pollution control measures in the nation's waters, inclusive of River Galma.

River Galma not only supplies the bulk of water used in Zaria Metropolis and its environs, but also provides wild fishes of varying species to the populace, thus there's an inherent need to periodically, rationally and systematically assess the heavy metals in the river ecological system. This study, therefore, investigates the risk of heavy metals in wild and farmed Clarias gariepinus in Zaria Metropolis against possible health hazards. The objectives include determining the variation of heavy metals accumulation in the two fish samples, the variation in the various fish tissues, the impact of heavy metals on the fishing zone and the possible individual health risk assessment with respect to the recommended fish daily intake by the $\mathrm{FAO} / \mathrm{WHO}$.

\section{MATERIALS AND METHODS}

\section{a. The Study Area}

Zaria metropolis has a total land area of over $300 \mathrm{~km}^{2}$ (115.831 square miles) and is located on latitude $11^{\circ} 04^{\prime \prime}$ north of the equator and longitude $7^{\circ} 42^{\prime \prime}$ east of the Greenwich Meridian. River Galma which spans the city is located towards the south eastern part of Zaria metropolis, in Dakace industrial layout (Nnaji et al., 2007); it boasts of industries such as Zarinject (a pharmaceutical company), Sunseed Oil Mill (vegetable oil processing mill), Zaria Industries Limited (a packaging firm) and several food and beverages companies. Outside the industrial layout, Zaria is also home to British American Tobacco Company, Zaria Ginnery, Ahmadu Bello University, Nigeria College of Aviation, Federal College of Education, Nuhu Bamalli Polytechnic and the famous Sabon-gari and TudunWada Markets. These businesses generate both industrial and domestic wastes, which is finally emptied into River Galma with little or no treatment, with effluents from other tributaries such as River Kubanni and River Tsaye emptying into it. The Galma River basin is also an agricultural beehive, with crops planted throughout the year. As such, fertilizers, insecticides and herbicides used on these crops are subsequently washed into the river via surface runoff (Nnaji et al., 2011).

\section{b. Instrumentation, Quality Assurance and Chemicals}

The instruments used were a Varian AA240 Fast Sequential Flame Atomic Absorption Spectrophotometer (AAS) and vapour generation 
accessory (Varian VGA 77) with closed end cell used for $\mathrm{Hg}$ determination in the Multi-User Science Research Laboratory (MSRL), Ahmadu Bello University, Zaria. With the lack of standard reference material, nitrate salts of the metals were used to prepare multi-element standard solution (MESS), for spiking recoveries in the validation of digestion method. The analysed samples were spiked and run in AAS again, of which the metal contents concentrations were determined from the calibration curve. The volume of spiked metals obtained was used to compute the percentage recoveries ( $\mathrm{R} \%$ ) as follows:

$$
\mathrm{R} \%=\left(\mathrm{C}_{1}-\mathrm{C}_{2}\right) \div \mathrm{C}_{3} \times 100
$$

Where $\mathrm{C}_{1}=$ Spiked Sample, $\mathrm{C}_{2}=$ Un-spiked Sample, $\mathrm{C}_{3}=$ MESS Concentration.

Method validation, was modified from Abubakar et al. (2015) by conducting limit of detection (LOD), limit of quantification (LOQ), and precision relative standard deviation $\left(R S D_{r}\right)$ for repeatability within the laboratory was also assessed with consideration to six levels of standard solutions $(n=6)$ with concentration values ranging between 0.1 and $2.5 \mathrm{mg} \cdot \mathrm{kg}^{-1}$ which were prepared. Evaluation of metal concentrations was carried out in triplicates per sample of fish tissues. Dilution factors of collected data were corrected by calculations and the values were presented in the units of $\mathrm{mg} \cdot \mathrm{kg}^{-1}$. LOD, LOQ, and $\mathrm{RSD}_{\mathrm{r}} \%$ were determined based on the standard deviation of the blanks, using the following:

$$
\begin{aligned}
& \mathrm{LOD}=x_{\text {blank }}+3 S_{\text {blank }} \\
& \mathrm{LOQ}=x_{\text {blank }}+10 S_{\text {blank }} \\
& \mathrm{RSD}_{\mathrm{r}} \%=(S / x) \times 100
\end{aligned}
$$

Where $x_{\text {blank }}=$ Blank Aqueous Solution Mean, $S_{\text {blank }}=$ Blank Standard Deviation.

Reagents used are all chemical grades from Sigma Company. Deionized-distilled water was used throughout the experimentation. Plastic containers, trays, and dissecting blades were washed in Deionized-distilled water, while glass wares were immersed in $10 \% \mathrm{HNO}_{3}$ for 24 hours, and thereafter rinsed with deionized-distilled water. The digested samples, including blanks were carried out in a clean laboratory environment.

\section{c. Fish Collection}

Twelve wild fish samples were collected from River Galma, with the help of local fishermen using long line and nets, between June and August of 2015. While another twelve farmed fish samples were collected from concrete based ponds, from a fish farm in Dakace industrial layout in Zaria metropolis, using hand nets. After collection, the samples were washed with deionized distilled water, identified, measured, weighed and thereafter stored in pre-cleaned plastic bags inside an ice-box, then transported to the laboratory. In the laboratory the samples were then frozen at $-20^{\circ} \mathrm{C}$ in a deep freezer unit until analysis.

\section{d. Fish Pre-treatment and Dissection}

Dissection was carried out after frozen fish samples thawed, washed with deionized-distilled water and allowed to reach room temperature in desiccators. Skin and muscle tissues were obtained using the Trucut method (Baker et al., 2004); scute skin of Clarias gariepinus from the dorsal region were removed using a sterilized notched needle. The out barrel was inserted into the fish muscle, after which the notched needle was extended into the flesh with a containment cover sliding over to cut the muscle tissue and placed in a labelled glass petri-dish. The skin on the outer side was then cut off ensuring that no part of the muscle was attached and placed in a labelled drying dish.

Removal of liver, kidney, brain, intestine, bone tissues and gills was done using a modified NIVA method by Rosseland et al. (2001). Dissections were done on plane plastic trays to separate sample organs. Operculum was raised and cut to expose gill arch, filament and rake, which were subsequently cut out. Whole intestine was removed and placed in a drying dish. The head of Clarias gariepinus was cut laterally through to the back of the skull, to expose brain, which was cut out. Vertebrae bones were cut out from the base of the skull to the tail, and placed in drying container after ridding it of flesh. All organs were oven dried at $80^{\circ} \mathrm{C}$ and cooled in desiccators and powdered in porcelain mortar and pestle.

\section{e. Sample Digestion}

Sample organs digestion were done using microwave assisted wet digestion method modified by Taghipour and Aziz (2010); $1 \mathrm{~g}$ of dry weight samples placed in polytetrafluoroethylene (PTFE) tube was microwaved. Digestion reagents i.e. a mixture of $6 \mathrm{ml}$ nitric acid $(65 \%)$ and $2 \mathrm{ml}$ Hydrogen peroxide $(35 \%)$ were added and placed in a microwave oven, the cleared solution was then diluted with deionized-distilled water to $50 \mathrm{ml}$ for skin, muscle, liver, intestine, kidney, brain and gills. Mixture was heated for 2 minutes and cooled to $25^{\circ} \mathrm{C}$.

\section{f. Risk Assessment}

In this study, risk assessment was determined by using only the muscle tissues (edible part) to evaluate the Daily Intake of Metal (DIM) and Health Risk Index (HRI) as espoused by Khan et al (2009), Okunola et al. (2011) and Abubakar et al. (2015).

i. DIM - Daily intake of metals (DIM) the daily intake of metals was calculated to estimate the daily loading of metals into the body system (via the consumption of fish meal specified in this study) of a specified body weight of a consumer. This would entail the relative bioavailability of the studied metals in this study. The DIM was determined using the following: 
$D I M=\left(C_{\text {metal }} \times D_{\text {fish }} \times C_{\text {factor }}\right) \div B_{\circ}$ (Chary et al., 2008)

Where $\mathrm{C}_{\text {metal }}=$ Concentration of heavy metal in Fish, $D_{\text {fish }}=$ Daily nutritional intake of fish, $\mathrm{C}_{\text {factor }}=$ Conversion of fresh fish to dry constant weight factor, $\mathrm{B}_{0}=$ Average Body Weight. The $\mathrm{C}_{\text {factor }}$ was calculated using the following:

$$
\begin{aligned}
& C_{\text {factor }}=I R_{w w}-I R_{d w} \\
& I R_{w w}=I R_{d w}[(100-W)] \div 100
\end{aligned}
$$

Where $I R_{d w}=$ Dry weight intake rate, $I R_{w w}=$ Wet weight intake rate, $\mathrm{W}=$ Percentage of water content in raw muscles (which is $64.8 \%$ for Clarias gariepinus was used in this study). Thus, in this study the $\mathrm{C}_{\text {factor }}$ for Clarias gariepinus was calculated as 0.352 using the above formulas, where the daily nutritional requirement was $100 \mathrm{~g}$ for adults (18 years and above), with average body weight of $70 \mathrm{~kg}, 80 \mathrm{~g}$ for children (6-18 years) with mean body weight of $48 \mathrm{~kg}$ and $60 \mathrm{~g}$ for children (less than 6 years) with average body weight of $19 \mathrm{~kg}$, as suggested by Portier et al. (2007).

ii. HRI - The populations' health risk index (HRI) through the consumption of contaminated feed was evaluated using the DIM in relation to the relative reference oral dosage $\left(R_{f} D\right)$ permitted for each metal. The index is used for assessing an individuals' risk of exposure to heavy metals. A HRI value of one (1) and less depicts a safe level and considered acceptable, however, any value above 1 is a potential heavy metal risk, and is calculated as follows:

$$
\mathrm{HRI}=\mathrm{DIM} \div \mathrm{R}_{\mathrm{f}} \mathrm{D} \text { (Jan et al., 2010) }
$$

\section{g. Statistical Analysis}

The data on heavy metal concentrations in the fish tissues of Clarias gariepinus were expressed with means and standard deviations. ANOVA was employed to show if there exists any significant difference between the wild and farmed fish species, and was followed by a post hoc analysis (DMRT), to establish the degree of relationship among the metal concentrations between the fish's culture media Pearson correlation was used with the aid of IBM SPSS version 20 , a statistical software package.

\section{Results and Discussion}

\section{a. Quality Assurance}

Table 1: Quality assurance for Mean Concentration of Metals in C. Gariepinus species

\begin{tabular}{llcccc}
\hline $\begin{array}{l}\text { Heavy } \\
\text { Metals }\end{array}$ & Tissues & $\begin{array}{c}\text { LOD }(\mathbf{m g} / \mathbf{k g}) \\
\mathbf{N = 6}\end{array}$ & $\begin{array}{c}\text { LOQ }(\mathbf{m g} / \mathbf{k g}) \mathbf{N} \\
\mathbf{6} \mathbf{6}\end{array}$ & $\begin{array}{c}\% \text { Recovery } \pm \\
\text { SD }\end{array}$ & $\%$ RSD $r$ \\
\hline $\mathbf{C d}$ & Skin & 0.052 & 0.105 & $104.3 \pm 0.25$ & 23.81 \\
$\mathbf{P b}$ & Muscles & 0.001 & 0.013 & $101.6 \pm 0.10$ & 11.11 \\
$\mathbf{H g}$ & Gills & 0.001 & 0.006 & $114.5 \pm 0.25$ & 20.83 \\
$\mathbf{F e}$ & Liver & $7.5 \mathrm{E}-05$ & 0.00061 & $102.7 \pm 0.35$ & 32.96 \\
$\mathbf{~ N i}$ & Intestine & 0.016 & 0.056 & $99.8 \pm 0.15$ & 2.69 \\
$\mathbf{C d}$ & Kidneys & 0.011 & 0.031 & $96.3 \pm 0.30$ & 5.14 \\
$\mathbf{P b}$ & Brain & 0.006 & 0.012 & $104.3 \pm 0.35$ & 36.98 \\
$\mathbf{H g}$ & Bones & 0.004 & 0.008 & $103.9 \pm 0.15$ & 15.74 \\
\hline
\end{tabular}

Table 1 shows the results of the validation parameters for the analytical procedures, which includes the recoveries of spiked fish tissues acquired for the heavy metals investigated (namely, $\mathrm{Cd}, \mathrm{Pb}, \mathrm{Hg}, \mathrm{Fe}$ and $\mathrm{Ni}$ ), which varied in ranges between $96.3 \%$ to $114.5 \%$. Acceptable recoveries were obtained for all cases, which indicate that the digestion method and AAS analysis used for the fish samples were reliable. In addition, when appraised in contrast with the Standard Operating Procedure (SOP) (USEPA, 2011) and the European Commission Regulation (ECR, 2007), the recoveries data in this study showed that the values were all within the range of $90-120 \%$, which are in compliance with values recommended by the named bodies.

Evaluated results of LOD (Limit of Detection), LOQ (Limit of Quantification) and RSD (Precision Relative Standard Deviation) within the laboratory repeatability authenticate the methods of experimental analysis employed, which is also shown in Table 1 with respect to the entire metals show that the LOD values of specification is not greater than one tenth and LOQ values not more than one fifth, as specified by the USEPA regulations (USEPA, 2011).

\section{c. Concentrations of Metals}

Statistical analysis of heavy metals concentrations $\left(\mathrm{mg} \cdot \mathrm{kg}^{-1}\right)$ of Cadmium, Lead, Mercury, Iron and Nickel in the organs/tissues (skin, gills, muscle, brain, bones, intestine, liver and kidney) of the two species of fishes (Clarias gariepinus) across the two culture media (wild and farmed) using means and standard deviation is shown in Table 2. Analysis of variation between the samples collected from the two culture media and samples collected from the two fish species showed significant differences $(P<0.05)$. 
Table 2: Mean and Standard Deviation of Metals Concentration in Tissues of $C$. gariepinus (mg.kg $\left.{ }^{-1}\right)$ Wet Weight

\begin{tabular}{|c|c|c|c|c|c|c|}
\hline $\begin{array}{l}\text { Tissue/ } \\
\text { Organ }\end{array}$ & & $\mathrm{Cd}(\mathrm{N}=12)$ & $\mathrm{Pb}(\mathrm{N}=12)$ & $\mathrm{Hg}(\mathrm{N}=12)$ & $\mathrm{Fe}(\mathrm{N}=12)$ & $\mathrm{Ni}(\mathrm{N}=12)$ \\
\hline \multirow{2}{*}{ Skin } & Wild & $0.13 \pm 0.025$ & $0.18 \pm 0.2$ & $0.325 \pm 0.38$ & $0.315 \pm 0.030$ & $0.118 \pm 0.12$ \\
\hline & Farmed & $0.005 \pm 0.0015$ & $0.001 \pm 0.001$ & $0.001 \pm 0.0004$ & $0.151 \pm 0.092$ & $0.0025 \pm 0.001$ \\
\hline \multirow{2}{*}{ Muscle } & Wild & $0.15 \pm 0.005$ & $0.24 \pm 0.195$ & $0.39 \pm 0.40$ & $0.45 \pm 0.032$ & $0.142 \pm 0.085$ \\
\hline & Farmed & $0.037 \pm 0.015$ & $0.0024 \pm 0.016$ & $0.040 \pm 0.015$ & $0.24 \pm 0.12$ & $0.0042 \pm 0.005$ \\
\hline \multirow{2}{*}{ Gills } & Wild & $0.04 \pm 0.01$ & $0.36 \pm 0.28$ & $0.25 \pm 0.15$ & $0.63 \pm 0.69$ & $0.065 \pm 0.070$ \\
\hline & Farmed & $0.025 \pm 0.020$ & $0.003 \pm 0.005$ & $0.0038 \pm 0.005$ & $0.28 \pm 0.25$ & $0.0017 \pm 0.0015$ \\
\hline \multirow{2}{*}{ Liver } & Wild & $0.07 \pm 0.030$ & $0.087 \pm 0.053$ & $0.490 \pm 0.10$ & $0.98 \pm 0.08$ & $0.065 \pm 0.020$ \\
\hline & Farmed & $0.018 \pm 0.002$ & $0.015 \pm 0.02$ & $0.0018 \pm 0.0020$ & $0.32 \pm 0.37$ & $0.018 \pm 0.015$ \\
\hline \multirow{2}{*}{ Intestine } & Wild & $0.062 \pm 0.01$ & $0.28 \pm 0.13$ & $0.094 \pm 0.010$ & $0.44 \pm 0.38$ & $0.008 \pm 0.006$ \\
\hline & Farmed & $0.002 \pm 0.07$ & $0.12 \pm 0.08$ & $0.0025 \pm 0.002$ & $0.15 \pm 0.17$ & $0.0028 \pm 0.001$ \\
\hline \multirow{2}{*}{ Kidney } & Wild & $0.267 \pm 0.040$ & $0.42 \pm 0.14$ & $0.41 \pm 0.15$ & $0.85 \pm 1.040$ & $0.0017 \pm 0.002$ \\
\hline & Farmed & $0.014 \pm 0.017$ & $0.048 \pm 0.030$ & $0.006 \pm 0.003$ & $0.28 \pm 0.25$ & $0.0065 \pm 0.005$ \\
\hline Brain & Wild & $0.019 \pm 0.015$ & $0.059 \pm 0.046$ & $0.0098 \pm 0.010$ & $0.45 \pm 0.42$ & $0.00157 \pm 0.001$ \\
\hline \multirow{2}{*}{ Bones } & $\begin{array}{l}\text { Farmed } \\
\text { Wild }\end{array}$ & $\begin{array}{l}0.007 \pm 0.009 \\
0.028 \pm 0.010\end{array}$ & $\begin{array}{l}0.004 \pm 0.005 \\
0.019 \pm 0.012\end{array}$ & $\begin{array}{l}0.0065 \pm 0.012 \\
0.085 \pm 0.030\end{array}$ & $\begin{array}{l}0.07 \pm 0.053 \\
0.65 \pm 0.28\end{array}$ & $\begin{array}{l}0.0023 \pm 0.0015 \\
0.0077 \pm 0.0041\end{array}$ \\
\hline & Farmed & $0.008 \pm 0.002$ & $0.004 \pm 0.0035$ & $0.0058 \pm 0.0032$ & $0.26 \pm 0.13$ & $0.00167 \pm 0.0021$ \\
\hline \multicolumn{2}{|c|}{ FAO/WHO (2003) } & 0.1 & 0.4 & 0.5 & 0.8 & 0.2 \\
\hline
\end{tabular}

\section{c. Concentrations of Heavy Metals}

i. Cadmium (Cd) - The results shows that Cadmium mean concentrations in wild Clarias gariepinus ranged from $0.019 \mathrm{mg} \cdot \mathrm{kg}^{-1}$ to $0.267 \mathrm{mg} \cdot \mathrm{kg}^{-1}$, for brain and kidney tissues, respectively, while farmed Clarias gariepinus showed mean concentrations of $0.002 \mathrm{mg} \cdot \mathrm{kg}^{-1}$ to $0.037 \mathrm{mg} \cdot \mathrm{kg}^{-1}$ which depicts $\mathrm{Cd}$ concentrations in the intestine and muscle tissues. Statistical significant differences $(P<0.05)$ were established among samples of wild and farmed tissues. In wild C. gariepinus significant differences were shown in sample tissues of brain and bones, while in farmed sampled tissues significant difference was shown in intestine and skin. The difference shown in wild and farmed fishes is very significant which indicates that cadmium contaminations were from different sources. The highest $\mathrm{Cd}$ concentration in wild fish tissue was in the liver $\left(0.267 \mathrm{mg}^{-1} \mathrm{~kg}^{-1}\right)$, which is also same for farmed fish with $0.028 \mathrm{mg} \cdot \mathrm{kg}^{-1}$. The concentration of $\mathrm{Cd}$ in the liver at very high levels was reported by Storelli et al. (2011), as Cd concentration obtained from Sphyrna zygaena species showed over $19.75 \mathrm{mg} . \mathrm{kg}^{-1}$ and Bashir et al. (2012) reported a Cd concentration of $13.35 \mathrm{mg} \cdot \mathrm{kg}^{-1}$ in $A$. thalassinus, while in Scomber scombrus, Abubakar et al. (2015) reported $\mathrm{Cd}$ concentrations of $19.75 \mathrm{mg} \cdot \mathrm{kg}^{-1}$. The lowest $\mathrm{Cd}$ concentration in wild $C$. gariepinus was in the brain $0.019 \mathrm{mg}^{\mathrm{kg}}{ }^{-1}$; while in the farmed $C$. gariepinus the skin $\left(0.005 \mathrm{mg} \cdot \mathrm{kg}^{-1}\right)$ had the lowest Cd concentration. The high concentration of $\mathrm{Cd}$ in the liver is not unconnected to the fact that the liver is the principal organ responsible for detoxification, transportation and storage of toxic substances, thus it is an active site for pathological effects induced by contamination (Uzairu et al., 2009).

ii. Lead $(\mathbf{P b})$ - Table 2 also shows that tissues/organs in wild $C$. gariepinus have concentration ranging from $0.019 \mathrm{mg} \cdot \mathrm{kg}^{-1}$ (bones) to $0.42 \mathrm{mg} \mathrm{kg}^{-1}$ (Kidney), while mean concentrations in farmed $C$. gariepinus ranged between $0.001 \mathrm{mg} \cdot \mathrm{kg}^{-1}$ on the skin and $0.12 \mathrm{mg} \mathrm{kg}^{-1}$ in the kidney. Statistical analysis indicates that a significant difference $(P<$ 0.05 ) was established between the two groups of fishes. The highest concentration of $\mathrm{Pb}$ in wild $C$. gariepinus was observed in the kidney $\left(0.42 \mathrm{mg}^{\mathrm{kg}} \mathrm{kg}^{-1}\right)$, while the lowest concentration was in the bone $\left(0.019 \mathrm{mg} \mathrm{kg}^{-1}\right)$. In the farmed group, the highest $\mathrm{Pb}$ concentration was obtained in the Kidney $(0.12 \mathrm{mg} . \mathrm{kg}$ $\left.{ }^{1}\right)$, while the skin was the lowest $\left(0.001 \mathrm{mg} \cdot \mathrm{kg}^{-1}\right)$. Sahar et al. (2014) reports that higher concentration of lead were found in the kidneys as opposed to liver, due to the fact that much detoxification has being carried out in the liver which is then accumulated in the kidneys. However, inactive tissues such as the bones, brains and muscles of fishes have been reported by Karadede et al. (2004), Ishaq et al. (2011) and Assante et al. (2014) to have low bio-accumulation rates of heavy metals, thus it does not reflect a factual metal concentration of a habitat. This is responsible for the low concentrations of $\mathrm{Pb}$ found in bones, brain and skin of both the wild and farmed $C$. gariepinus in this study. It is pertinent to note that Lead is classified as one of the most lethal metals, without any known benefits to humans or animals, but has been known to 
cause oxidative damage to the heart, kidney, brain (cognitive impairment) and reproductive organs (Singh et al., 2011).

iii. $\quad$ Mercury $(\mathbf{H g})$ - Mean concentrations for $\mathrm{Hg}$ as shown in Table 2 indicates a range which varies from $0.001 \mathrm{mg} \cdot \mathrm{kg}^{-1}$ in the skin to $0.04 \mathrm{mg} \cdot \mathrm{kg}^{-1}$ in the muscle of farmed $C$. gariepinus. In the wild batch the liver had the highest $\mathrm{Hg}$ concentrations with $0.49 \mathrm{mg} \cdot \mathrm{kg}^{-1}$, while the lowest was obtained in the brain $\left(0.0098 \mathrm{mg}^{\mathrm{kg}} \mathrm{k}^{-1}\right)$. However, there wasn't any significant difference $(P<0.05)$ between the two groups. Liver and brain tissues have been reported to have as much as $70.9 \mathrm{mg} \cdot \mathrm{kg}^{-1}$ and $76 \mathrm{mg} \cdot \mathrm{kg}^{-1}$ respectively (Abubakar et al., 2015) $\mathrm{Hg}$ concentrations, but $\mathrm{Hg}$ in the brain of C. gariepinus in this study showed very low concentrations in wild $\left(0.0098 \mathrm{mg} \cdot \mathrm{kg}^{-1}\right)$ and farmed groups $\left(0.0065 \mathrm{mg} \cdot \mathrm{kg}^{-1}\right)$, which differed markedly with Abubakar et al. (2015) and Mieiro et al. (2011), who all advanced that the brain is one of the vital organs in fish that stores very high levels of mercury. However, $\mathrm{Hg}$ gets into fish tissues mainly through absorption and ingestion by the skin and gills (Mieiro, 2011), which gives reason for the high $\mathrm{Hg}$ concentrations in the skin $\left(0.325 \mathrm{mg} \cdot \mathrm{kg}^{-1}\right)$, gills $\left(0.25 \mathrm{mg} \cdot \mathrm{kg}^{-1}\right)$ and muscle $\left(0.39 \mathrm{mg} . \mathrm{kg}^{-1}\right)$ of wild $C$. gariepinus. A wide spectrum of adverse health effects is associated with excessive exposure to mercury, which includes neurotoxicity to the Central Nervous System (CNS) and kidney damage in humans (Mieiro et al., 2011). With exception of the liver tissue in wild $C$. gariepinus, both groups of sampled fishes had $\mathrm{Hg}$ concentrations below the $\mathrm{FAO} / \mathrm{WHO}$ recommended exposure level of $0.5 \mathrm{mg} \cdot \mathrm{kg}^{-1}$.

iv. Iron (Fe) - Table 2 also shows the concentration levels of $\mathrm{Fe}$ was lowest in the brain of farmed $C$. gariepinus $\left(0.07 \mathrm{mg} . \mathrm{kg}^{-1}\right)$, while the highest was recorded in the liver $\left(0.32 \mathrm{mg} \cdot \mathrm{kg}^{-1}\right)$. In the wild species the liver also accounted for the highest $\left(0.98 \mathrm{mg} \mathrm{kg}^{-1}\right)$, while the lowest reading of $\mathrm{Fe}$ was obtained in the skin. Statistical analysis showed that there's no significant difference $(P<0.05)$ between both groups, thus the path of contamination is homogenous. The liver and kidney in wild $C$. gariepinus accounted for $\mathrm{Fe}$ concentrations (0.98mg. $\mathrm{kg}^{-1}$ and $0.85 \mathrm{mg} \cdot \mathrm{kg}^{-1}$, respectively) which were above the $\mathrm{FAO} / \mathrm{WHO}$ standard safety limits (0.8 $\mathrm{mg} \cdot \mathrm{kg}^{-1}$ ) but were remarkably lower when compared to results obtained by Abubakar et al. (2015) where they showed Fe concentrations as high as $375.93 \mathrm{mg}^{-1} \mathrm{~kg}^{-1}$ in the liver, $225.25 \mathrm{mg} \mathrm{kg}^{-1}$ in the gills, $15.89 \mathrm{mg} \cdot \mathrm{kg}^{-1}$ in the skin, $11.44 \mathrm{mg} \cdot \mathrm{kg}^{-1}$ in the muscles, all in Scomber scombrus imported into Nigeria from Russian and European shipping origins. Their report was synonymous with those of Erhan et al. (2004) who recorded $\mathrm{Fe}$ concentrations of $200.86 \mathrm{mg} \cdot \mathrm{kg}^{-1}$ in liver tissues of Liza abu and Bashir et al. (2013) showed Fe concentrations of $1007.1 \mathrm{mg} \cdot \mathrm{kg}^{-1}$ and $1975 \mathrm{mg} \cdot \mathrm{kg}^{-1}$ in $A$. thalassinus and $P$. Anea, respectively. It should be noted that $\mathrm{Fe}$ is an essential component of proteins and it is involved in the transportation of oxygen from the lungs to other tissues, prompting Kumar and
Mukherjee (2011) and Mieiro (2011) to assert that the high level of $\mathrm{Fe}$ in liver tissues is as a result of the large volume of blood present, thus $\mathrm{Fe}$ accumulates more in liver tissues than any other tissues. However, very high amounts of $\mathrm{Fe}$ in human systems causes' rapid increase in pulse rate and coagulation of blood in blood vessels.

v. Nickel (Ni) - A ubiquitous element in the environment, Nickel is almost certainly essential for animal nutrition, and consequently essential to man (WHO, 2010, FAO, 2012) in trace quantities. However, the FAO (2012) further reiterates that $\mathrm{Ni}$ despite being a relatively non-toxic element; it has shown to be carcinogenic in animal experiments when in combination with certain chemical compounds. In Table 2 Ni concentrations in wild $C$. gariepinus ranged between $0.00157 \mathrm{mg} \mathrm{kg}^{-1}$ in the brain and $0.142 \mathrm{mg} \cdot \mathrm{kg}^{-1}$ in the muscle tissues. Furthermore, in the farmed species the highest concentration was obtained in the liver $\left(0.018 \mathrm{mg} \mathrm{kg}^{-1}\right)$ and $0.00167 \mathrm{mg} . \mathrm{kg}^{-1}$ in the bone was the lowest. A wide disparity when compared to reports of Abubakar et al. (2015), Israa et al. (2009), and Erhan et al. (2004) who all reported over $8 \mathrm{mg} \cdot \mathrm{kg}^{-1}$ of $\mathrm{Ni}$ concentrations in the liver of various fish species. Although, the mean concentration of $\mathrm{Ni}$ in both wild and farmed $C$. gariepinus is less than the FAO/WHO safety limits of $0.2 \mathrm{mg} \cdot \mathrm{kg}^{-1}$, it is still very significant if the consequence generated by the addition of other chemical is put in perspective.

The summary of the heavy metals $(\mathrm{Cd}, \mathrm{Pb}$, $\mathrm{Hg}$, $\mathrm{Fe}$ and $\mathrm{Ni}$ ) studied in the analysed tissues of both the wild and farmed $C$. gariepinus was summarized in the trend of accumulation pattern in the following order $\mathrm{Fe}>\mathrm{Hg}>\mathrm{Pb}>\mathrm{Cd}>\mathrm{Ni}$. There was very high concentration of Iron when viewed in parallel with the other analysed heavy metals, which is as a result of both natural and anthropogenic factors that have had an impact on the water bodies from where the fishes were collected. Iron is an essential trace element required by all organisms, however, high concentrations could lead to heart, pituitary, thyroid, adrenals, liver and pancreas failure due to siderosis (Iron deposition in tissues) among other effects (Taweel et al., 2012). Unlike Iron, Mercury is a nonessential element, and was shown to be the second highest metal accumulating in tissues of $C$. gariepinus. Mercury has the potential to impact negatively on fishes as well as human health, but despite its continuous uptake, its elimination is not actively regulated (Capelli et al., 2008), which is a source of concern. However, fishes serve as bio-indicators in controlling aquatic pollution and thus any spike in levels of heavy metals in water bodies can be effectively appraised by analysis of fish tissues. The concentrations of Cadmium and Nickel were the least accumulated metals, conversely, excessive exposures to Nickel cause nasal and lung cancers, while Lead was also reported in appreciable concentrations.

Heavy metals concentrations in the tissues of C. gariepinus were studied and discovered to be in very low quantities when compared with $\mathrm{FAO} / \mathrm{WHO}$ safety limits, thus both natural and anthropogenic 
activities can be said to be moderate in the area where the fishes were collected, most especially the farmed species.

\section{d. Risk Assessment}

The risk assessment of heavy metals $(\mathrm{Cd}, \mathrm{Pb}, \mathrm{Hg}, \mathrm{Fe}$ and $\mathrm{Ni}$ ) in the muscle tissues of $C$. gariepinus were evaluated in both the wild and farmed species, and were reported in mean, standard deviation, individual variations, daily intake of metal (DIM) and health risk index (HRI) which is summarized in Table 3.

Table 3: DIM and HRI Individual's Responses for Heavy Metals in Muscle Tissue of $C$. gariepinus species

\begin{tabular}{|c|c|c|c|c|c|}
\hline $\begin{array}{l}\text { Heavy } \\
\text { Metal }\end{array}$ & $\begin{array}{l}\text { Range (N = 24, } \\
\text { mg.kg-1) }\end{array}$ & $\begin{array}{l}\text { Mean } \pm \text { SD } \\
(\text { mg.kg-1) }\end{array}$ & Individual Category & $\begin{array}{l}\text { DIM (mg.kg-1 } \\
\text { day-1) }\end{array}$ & HRI \\
\hline \multirow[t]{3}{*}{ Cd } & $0.019-0.27$ & $0.15 \pm 0.010$ & Adult (19 years \& Above) & $7.54 \mathrm{E}-5$ & 7.54E-4 \\
\hline & & & Teen ( 7 - 18 years) & $8.08 \mathrm{E}-5$ & $8.80 \mathrm{E}-4$ \\
\hline & & & Children ( $1-6$ years) & $1.66 \mathrm{E}-4$ & $1.66 \mathrm{E}-3$ \\
\hline \multirow[t]{3}{*}{$\mathbf{P b}$} & $0.019-0.42$ & $0.24 \pm 0.010$ & Adult (19 years \& Above) & $1.21 \mathrm{E}-4$ & 3.02E-4 \\
\hline & & & Teen ( 7 - 18 years) & $1.41 \mathrm{E}-4$ & $3.52 \mathrm{E}-4$ \\
\hline & & & Children ( $1-6$ years) & 2.67E-4 & 6.67E-4 \\
\hline \multirow[t]{3}{*}{$\mathrm{Hg}$} & $0.098-0.49$ & $0.39 \pm 0.040$ & Adult (19 years \& Above) & $1.96 \mathrm{E}-4$ & 3.92E-4 \\
\hline & & & Teen ( 7 - 18 years) & 2.29E-4 & $4.58 \mathrm{E}-4$ \\
\hline & & & Children ( $1-6$ years) & 4.34E-4 & 8.67E-4 \\
\hline \multirow[t]{3}{*}{$\mathbf{F e}$} & $0.315-0.98$ & $0.45 \pm 0.240$ & Adult (19 years \& Above) & $2.26 \mathrm{E}-4$ & 2.83E-4 \\
\hline & & & Teen ( 7 - 18 years) & $2.64 \mathrm{E}-4$ & 3.30E-4 \\
\hline & & & Children ( $1-6$ years) & $5.00 \mathrm{E}-4$ & $6.25 \mathrm{E}-4$ \\
\hline \multirow[t]{3}{*}{$\mathbf{N i}$} & $0.00157-0.14$ & $0.142 \pm 0.042$ & Adult (19 years \& Above) & 7.14E-5 & 3.57E-4 \\
\hline & & & Teen ( 7 - 18 years) & 8.33E-5 & 4.17E-4 \\
\hline & & & Children ( 1 - 6 years) & $1.58 \mathrm{E}-4$ & $7.89 \mathrm{E}-4$ \\
\hline
\end{tabular}

Cadmium concentration in the muscle tissues of $C$ gariepinus had a mean $0.15 \mathrm{mg} \cdot \mathrm{kg}^{-1}$ across the 24 sampled fishes of wild and farmed origins. Individual assessments were based on the average body weight in relation to the age groups. DIM results showed individuals' daily loading of $\mathrm{Cd}$ to be $7.45 \times 10^{-5}, 8.08 \times$ $10^{-5}$ and $1.66 \times 10^{-4} \mathrm{mg} \cdot \mathrm{kg}^{-1}$. These recordings corresponded to HRI ratio of less than one (1) in each of the age category. Relative to the recommended daily intake values, as specified in this study, the results justifies that the individuals are not exposed to any high dosage of $\mathrm{Cd}$ with the consumption of fish muscles.

The mean concentrations of $\mathrm{Pb}$ was 0.24 mg. $\mathrm{kg}^{-1}$ in all 24 samples of fish muscles belonging to C. gariepinus, with DIM results showing individual's daily loading of Lead as $1.21 \times 10^{-4}, 1.41 \times 10^{-4}$ and $2.67 \times 10^{-4}$. The records corresponded to HRI ratio of less than one (1) in each of the age category. Relative to the recommended daily intake values, as specified in this study, the results justifies that the individuals are not exposed to any high dosage of $\mathrm{Pb}$ with the consumption of fish muscles.

Mercury concentrations in the muscle tissues of $C$. gariepinus had a mean of $0.39 \mathrm{mg} \cdot \mathrm{kg}^{-1}$ across the 24 sampled fishes of wild and farmed origins. Individual assessments were also based on the average body weight in relation to the age groups, with DIM results showing individuals' daily loading of $\mathrm{Hg}$ as $1.96 \times 10^{-4}, 2.29 \times 10^{-4}$ and $4.34 \times 10^{-4} \mathrm{mg} \cdot \mathrm{kg}^{-1}$. The results indicates that with a HRI ratio of less than one (1) in each of the age category, individuals are not exposed to any high dosage of $\mathrm{Hg}$ with the consumption of fish muscles, based on the recommended daily intake values, as specified in this study.

The mean concentrations of $\mathrm{Fe}$ was 0.45 mg. $\mathrm{kg}^{-1}$ in all 24 samples of fish muscles belonging to C. gariepinus, with DIM results showing individual's daily loading of Iron as $2.26 \times 10^{-4}, 2.64 \times 10^{-4}$ and $5.00 \times 10^{-4}$. The records corresponded to HRI ratio of less than one (1) in each of the age category. Relative to the recommended daily intake values, as specified in this study, the results justifies that the individuals are not exposed to any high dosage of $\mathrm{Fe}$ with the consumption of fish muscles.

Nickel concentrations in the muscle tissues of C. gariepinus had a mean of $0.142 \mathrm{mg} \cdot \mathrm{kg}^{-1}$ across the 24 sampled fishes of wild and farmed origins. Individual assessments were also based on the average body weight in relation to the age groups, with DIM results showing individuals' daily loading of $\mathrm{Ni}$ as $7.14 \times 10^{-5}, 8.33 \times 10^{-5}$ and $1.58 \times 10^{-4} \mathrm{mg}^{-\mathrm{kg}^{-1}}$. The results indicates that with a HRI ratio of less than one (1) in each of the age category, individuals are not exposed to any high dosage of $\mathrm{Ni}$ with the consumption of fish muscles, based on the recommended daily intake values, as specified in this study. 
In summary results in Table 3 after the analysis of daily intake of metal (DIM) and health risk index (HRI) showed that the population of wild and farmed C. gariepinus (catfish) consumers in Zaria metropolis are not exposed to high doses of heavy metals $(\mathrm{Cd}, \mathrm{Pb}, \mathrm{Hg}, \mathrm{Fe}$ and $\mathrm{Ni}$ ) in all individual age category, as they were all below the $\mathrm{FAO} / \mathrm{WHO}$ acceptable limits.

\section{CONCLUSION}

A risk assessment of human health status with respect to heavy metals contamination in wild and farmed species of $C$. gariepinus consumed in Zaria metropolis was carried out in this study. Analysis obtained indicated no significant risk of human exposure to heavy metals $(\mathrm{Cd}, \mathrm{Pb}, \mathrm{Hg}, \mathrm{Fe}$ and $\mathrm{Ni}$ ) regarding consumption of $C$. gariepinus relative $\mathrm{FAO} / \mathrm{WHO}$ (2003) permissible limits; however, individuals consuming fish livers have higher risk ingesting toxic metals at unacceptable limits. Thus, since such hazards might occur, it is recommended that aquaculture practices of farmed fish is improved across the area, while environmental regulators ensure that industrial wastes are well treated before discharging into water bodies to further eliminate the risk of contamination. Finally, this study may make available valuable data for continuing research on aquaculture practices of wild and farmed fishes in Nigeria.

\section{CONFLICT OF INTERESTS}

The authors declare that there is no conflict of interests regarding this paper publication.

\section{ACKNOWLEDGEMENTS}

The authors wish to acknowledge the staff of the MultiUser Science Research Laboratory, and the Department of Biological Sciences, A.B.U, Zaria, for their support, constructive and analytical assistance.

\section{REFERENCE}

Abubakar A, Uzairu A; Ekwumemgbo PA and Okunola OJ (2015). Risk Assessment of Heavy Metals in Imported Frozen Fish Scomber scombrus Species Sold in Nigeria: A Case Study in Zaria Metropolis. Advances in Toxicology, Vol. 2: 1-12

Ali M and Soltan M (1996). The Impact of Three Industrial Effluents on Submerged Aquatic Plants in the River Nile, Egypt. Hydrobiologia, Vol. 340 (1-3): 77- 83.

Allen HE, Perdue EM and Brown DS (1993). Metals in Groundwater, Lewis Publishers, 437.

Amos TT and Bolorunduro PI (2000). Economics of Aquaculture Production. Extension Bulletin No 107 Fisheries Series No. 5. National Agricultural
Extension and Research Liaison Services, Ahmadu Bello University, Zaria, 1 - 31 .

Assante F, Agbeko EA, Addae G and Quainoo AK (2014). Bioaccumulation of heavy metals in water, sediments and tissues of some selected fishes from the Red Volta, Nangodi in the upper east region of Ghana. British Journal of Applied Science \&Technology, Vol.4 (4): 594-603.

Ashraf MA, Maah MJ and Yusoff I (2012). Bioaccumulation of Heavy Metals in Fish Species Collected From Former Tin Mining Catchment. International Journal of Environmental Research, Vol. 6 (1): 209-218.

Baker RF, Blanchfield PJ, Paterson MJ, Flett RJ and Wesson $L$ (2004). Evaluation of nonlethal methods for the analysis of mercury in fish tissue. Transactions of the American Fisheries Society, Vol.133 (3): 568-576.

Bashir FH, Othman MS, Mazlan AG, Rahim SM and Simon KD (2013). Heavy metal concentration in fishes from the coastal waters of Kapar and Mersing, Malaysia. Turkish Journal of Fisheries and Aquatic Sciences, Vol.13 (2): 375-382.

Brown FMJ and Balls PW (1997). Trace metals in fish and shellfish from Scottish waters. Scottish Fisheries Research Report No. 60, Environment and Fisheries Department, The Scottish Office Agriculture.

Capelli R, Das K and Pellegrini RD (2008). Distribution of trace elements in organs of six species of cetaceans from the Ligurian Sea (Mediterranean), and the relationship with stable carbon and nitrogen ratios. Science of the Total Environment, Vol. 390(2-3): 569-578.

CCFAC - Codex Committee on Contaminants in Foods (2011). Food Standards Programed: Joint FAO/WHO, Fifth Session, CCFAC (Codex Committee on Contaminants in Foods), The Hague, The Netherlands.

Chary NS, Kamala CT, and Raj DSS (2008). Assessing risk of heavy metals from consuming food grown on sewage irrigated soils and food chain transfer. Ecotoxicology and Environmental Safety Vol. 69: $513-524$.

ECR - European Commission Regulation (2007). Laying down the sampling methods and the methods of analysis for the official control of the lead, cadmium, mercury, inorganic tin, 3-MCPD and benzo (a) pyrene in foodstuffs, Tech. Rep. 333/2007, 2007.

Erhan U, Hulya K and Seyit AO (2004). Heavy metals in mullet, Liza abu, and catfish, Silurus triostegus, from the Atat"urk Dam Lake (Euphrates), Turkey. Environment International, Vol. 30 (2): 183-188.

FAO (2012). The state of world review of fisheries and aquaculture. Part $1, \quad 2012$, http://www.fao.org/docrep/016/i2727e/i2727e01.pd $f$

FAO (2003). Heavy Metals Regulations: Part 1. Legal Notice No. 66, 2003, http://www.faolex.fao.org/docs/pdf/eri42405.pdf. 
Forstner U and Wittmann GTW (1983). Metal pollution in the aquatic environment. Springer-Verlag, Berlin, 30-6.

Güven K, Özbay C, Ünlü E and Satar A (1999).. Acute lethal toxicity and accumulation of copper in Gammarus pulex (L.) (Amphipoda). Tropical Journal of Biology, 23 (1): 51-521

Hajeb $P$, Jinap $S$, Ismail $A$, Fatimah $A B$, Jamilah $B$ and Abdul Rahim M (2009). Assessment of mercury level in commonly consumed marine fishes in Malaysia. Food Control, Vol. 20 (1): 79-84.

Handy R (1994). Intermittent Exposure to Aquatic Pollutants Assessment, Toxicity and Sublethal Responses in Fish and Invertebrates. Comparative Biochemistry and Physiology C-Pharmacology Toxicology \& Endocrinology, Vol. 107 (2): 171184.

Herger $L$ and Edmond L (2012). Assessment of mercury in fish tissue from select lakes of Northeastern Oregon. Technical Report. EPA-910R-12-001, U.S. Environmental Protection Agency Region 10, 2012

Hu Y, Shang H and Tong $H$ (2009). Stable isotope dietary analysis of the Tianyuan 1 early modern human. Proceedings of the National Academy of Sciences of the United States of America, Vol. 106 (27): 10971-10974.

Ibeto CN and Okoye COB (2010). High levels of Heavy metals in Blood of Urban population in Nigeria. Research Journal of Environmental Sciences, Vol. 4 (4): 371-382.

Ishaq ES, Rufus $S$ and Annune PA (2011). Bioaccumulation of heavy metals in fish (Tilapia zillii and Clarias Gariepinus) organs from River Benue, North-Central Nigeria. Pakistan Journal of Analytical \& Environmental Chemistry, Vol.12 (1): 25-31.

Israa AJ, Luma HZ and Rana MA (2013). Bacterial and heavy metals analyses in fish at Shawaka area of Tigris River. Chemistry and Materials Research, Vol.3 (7): 94-100.

Jafari N G and Gunale VR (2006). Hydobiological study of algae of an urban freshwater river. Journal of Applied Science and Environmental Management, 10 (2): 153-158.

Jan FA, Ishaq M, Khan S, Ihsanullah I, Ahmad I, and Shakirullah M (2010). A comparative study of human health risks via consumption of food crops grown on waste water irrigated soil (Peshawar) and relatively clean water irrigated soil (lower Dir). Journal of Hazardous Materials, Vol. 179: 612 621.

Karadede H, Oymak SA and Unlu E (2004). Heavy metals in mullet, Liza abu, and catfish, Silurus triostegus, from the Atat" urk Dam Lake (Euphrates), Turkey, Environment International, Vol. 30 (2): 183-188.

Khan S, Farooq R, Shahbaz S, Khan MA and Sadique $M(2009)$. Health risk assessment of heavy metals for population via consumption of vegetables. World Applied Sciences Journal, Vol. 6 (12): 1602-1606

Kumar B and Mukherjee DP (2011). Assessment of human health risk for arsenic, copper, nickel, mercury and zinc in fish collected from tropical wetlands in India. Advances in Life Science and Technology, Vol. 2:13-25.

Meybeck M, Chapman D and Helmer R (1996). Global Fresh Water Quality: A second Assessment. Blackwell Reference. Oxford, 306-310

Mieiro CL, Coelho JP, Pacheco M, Duarte AC and Pereira ME (2012). Trace elements in two marine fish species during estuarine residency: nonessential versus essential. Marine Pollution Bulletin, Vol. 64 (12): 2844-2848.

Mieiro CL, Pereira ME, Duarte AC and Pacheco M (2011). Brain as a critical target of mercury in environmentally exposed fish (Dicentrarchus labrax)-bioaccumulation and oxidative stress profiles. Aquatic Toxicology, Vol.103 (3-4): 233240.

Nnaji CJ, Uzairu A, Harrison GFS, Balarabe ML (2011). Effect of Pollution on the PhysicoChemical Parameters of Water and Sediments of River Galma, Zaria, Nigeria. Research Journal of Environmental and Earth Science. Vol. 3 (4): 314-320

Okunola OJ, Alhassan $Y$ and Yebpella GG (2011). Risk assessment of using coated mobile recharge cards in Nigeria. Journal of Environmental Chemistry and Ecotoxicology, Vol.3 (4): 80-85.

Olaifa FE, Olaifa AK, Adelaja AA and Owolabi AG (2010). Heavy metal contamination of Clarias gariepinus from a lake and Fish farm in Ibadan, Nigeria. African Journal of Biomedical Research, Vol. 7 (3): 145-148.

Osman A (2007). Embryo-Toxic Effects of Lead Nitrate of the African Catfish Clarias Gariepinus (Burchell, 1822), PhD Thesis, Humboldt-University, Berlin.

Osman AG and Kloas W (2010). Water Quality and Heavy Metal Monitoring in Water, Sediments, and Tissues of the African Catfish Clarias gariepinus (Burchell, 1822) from the River Nile, Egypt. Journal of Environmental Protection, Vol. 1: 389-400.

Portier K, Tolson R and Roberts SM (2007). Body weight distributions for risk assessment. Risk Analysis, Vol.27 (1): 11-26.

Rosseland BO, Massabuau JC and Grimalt J (2001). Fish Ecotoxicology: The EMERGE Fish Sampling Manual for Live Fish, The EMERGE Project (European Mountain Lake Ecosystems: Regionalisation, Diagnostic and Socio-Economic Valuation).

Sahar M, Alireza P and Afshari R (2014). Analysis and determination of trace metals (nickel, cadmium, chromium, and lead) in tissues of Pampus argenteus and Platycephalus indicus in the Hara Reserve, Iran. Journal of Toxicology, Vol. 4: 6 12.

Singh R, Gautam N, Mishra A and Gupta R (2011). Heavy metals and living systems: An overview. Indian Journal of Pharmacology, Vol.43 (3): 246253.

Storelli MM, Normanno G and Barone G (2012). Toxic metals $(\mathrm{Hg}, \mathrm{Cd}$, and $\mathrm{Pb})$ in fishery products imported into Italy: suitability for human consumption. Journal of Food Protection, Vol.75 (1): 189-194. 
Taghipour V and Aziz SN (2010). Determination of trace elements in canned Kilka fish marketed in Islamic Republic of Iran. World Applied Sciences Journal, Vol. 9 (6): 704-707.

Taweel AKA, Shuhaimi-Othman $M$ and Ahmad AK (2012). Heavy metals concentration in Tilapia fish (Oerochomis niloticus) from four selected markets in Selangor, Peninsular Malaysia. Journal of Biological Sciences, Vol.10 (55): 1562- 1566.

USEPA (2011). Exposure Factors Handbook: 2011 Edition, EPA/600/R-090/052F, Office of Research and Development, Washington, DC, USA.

Uzairu A, Harrison GFS, Balarabe ML and Nnaji JC (2009). Concentration levels of trace metals in fish and sediment from Kubanni River, Northern Nigeria. Bulletin of the Chemical Society of Ethiopia, Vol.23 (1): 9-17.

WHO (2005). Background document for development of WHO guidelines for nickel in drinking-water quality and fish. Technical Report, WHO/Sde/Wsh/05.08/55.

Yilmaz, AB (2003). Levels of heavy metals (Fe, Cu, Ni, $\mathrm{Cr}, \mathrm{Pb}$, and $\mathrm{Zn}$ ) in tissue of Mugil cephalus and Trachurus mediterraneus from Iskenderun Bay, Turkey. Environmental Research, Vol. 92 (3): 277281.

Cite this Article: Onyidoh HE, Ismail FM, Muhammad AM \& Idris JA (2018). Risk Assessment of Heavy Metals in Wild and Farmed Clarias gariepinus (Burchell, 1822) in Zaria, Kaduna State, Nigeria. Greener Journal of Agricultural Sciences, 8(1): 012021, http://doi. org/10.15580/GJAS.2018.1.110217163. 